\title{
Pengaruh Jarak Penyekat dalam Fotobioreaktor Tubular terhadap Pertumbuhan Kultur Mikroalga Ankistrodesmus convulutus
}

\section{Influence of Partition Density in Tubular Photobioreactor on the Growth of Microalga Ankistrodesmus convulutus Culture}

\author{
Tjandra Chrismadha*, Tenni Rustiani, Rosidah, Yayah Mardiati \\ Puslit Limnologi LIPI, Kompleks LIPI Cibinong, Jl Raya Bogor Km 46, Cibinong \\ Ph 021 8757071, Fax 021 8757076, E-mail tjandra@indo.net.id *Penulis untuk korespondensi
}

\begin{abstract}
A series of partition was constructed inside a vertical tubular photobioreactor to control the culture distribution in obtaining intermittent exposure to light area in the surface of the tubular column. A microalga, Ankistrodesmus convulutus, was grown in a batch mode in the reactor with PHM medium, light sources of fluorescent lamp 3 x 40 watt $(I=5.500$ lux on the surface of the tubular) and room temperature of $27-31^{\circ} \mathrm{C}$. The experiment was carried out to study the influence of partition density which was constructed at varied distance, which were 1, 2 and 3 inch on the growth and biochemical composition of the alga. A vertical tubular photobioreactor without partition was applied as the control. The partition density did not significantly affect the optical density achievement of the culture, but it significantly affected the biomass and chlorophyll concentration, as well as the protein/carbohydrate ratio of the culture. It is believed that the intermittent exposure of algal cell to the light area leads to sincronization of the light and dark reaction of the photosynthesis, as well as to vapor the catalitic proccesses to develop the functional cell structure.
\end{abstract}

Keywords: Partition, tubular photobioreactor, microalga, Ankistrodesmus convulutus

Diterima: 11 Mei 2006, disetujui: 17 Oktober 2006

\section{Pendahuluan}

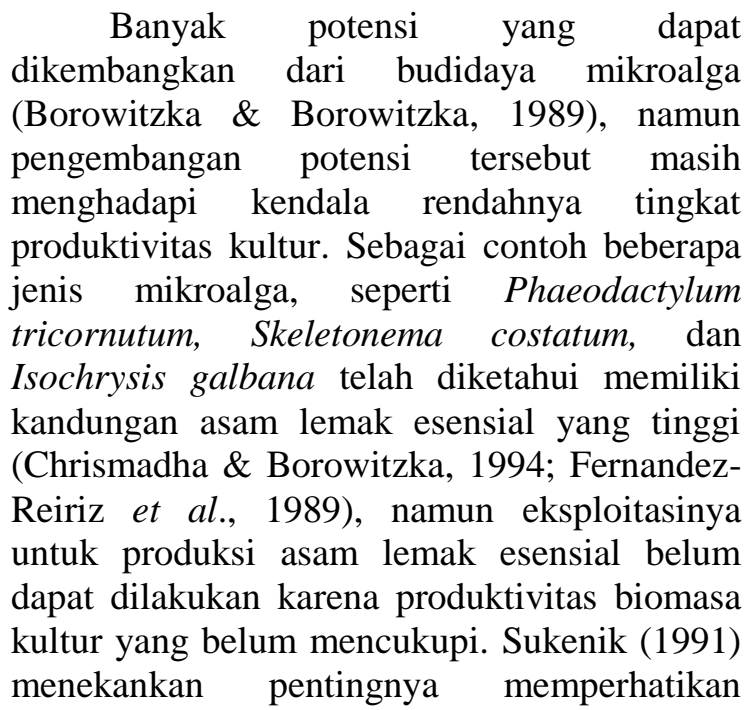

produktivitas biomasa dalam kaitan dengan kelayakan produksi asam lemak esensial menggunakan kultur mikroalga.

Fotobioreaktor tubular telah dilaporkan dapat meningkatkan laju fotosintesis kultur mikroalga. Peningkatan laju fotosintesis tersebut diduga disebabkan oleh terjadinya fenomena flashing light effect, meskipun peran fenomena tersebut masih belum difahami secara mendasar (Laws et al., 1988). Fenomena flashing light effect pada awalnya ditemukan di laut, dimana riak-riak air laut akibat gerak gelombang merefleksikan cahaya matahari yang datang secara acak ke dalam kolom air di sebelah dalamnya. Refleksi cahaya tersebut menciptakan kilatan-kilatan cahaya yang datang secara bertenggang (intermittant) ke permukaan sel-sel alga yang ada di dalam 
kolom air tersebut. Percobaan-percobaan di laboratorium memperlihatkan bahwa sel-sel alga mendapat keuntungan dari kondisi tersebut, yaitu dengan meningkatnya efisiensi fotosintesis (Grobbelaar, 1989). Chrismadha et al., (2002) juga melaporkan hubungan yang signifikan antara laju fotosintesis kultur Chlorella vulgaris dengan frekuensi intermitan cahaya dalam fotobioreaktor yang dilengkapi penyekat. Pada kultur Spirulina platensis kontrol interval waktu gelap-terang dengan pengadukan juga dilaporkan meningkatkan produktivitas kulturnya (Thonglek et al., 1997).

Beberapa ahli berpendapat bahwa, sementara siklus gelap terang harian dianggap menyediakan waktu yang cukup untuk sel-sel alga beradaptasi terhadap siklus cahaya tersebut, siklus cahaya bertenggang yang dihasilkan oleh pengadukan kultur berlangsung terlalu singkat untuk proses adaptasi seperti di atas, sehingga sel-sel alga beradaptasi pada intensitas cahaya rata-ratanya (Rabe \& Benoit, 1962; Raven, 1988). Sementara beberapa ahli lainnya mengaitkan peningkatan efisiensi fotosintesis tersebut dengan sinkronisasi waktu terjadinya reaksi gelap dan reaksi terang fotosintesis pada kultur tersebut, dimana fraksi gelap dari cahaya bertenggang memberikan waktu yang cukup bagi sel-sel alga untuk menyelesaikan proses reaksi gelap sebelum menerima energi cahaya untuk aktivasi proses fotosintesis selanjutnya (Goldman, 1979).

Di samping berpengaruh pada unjuk kerja fotosintesis kultur mikroalga, cahaya bertenggang diduga juga mempengaruhi komposisi biokimia sel alga, khususnya yang terkait dengan mekanisme adaptasi alga terhadap cahaya. Seperti telah dilaporkan sebelumnya, komposisi biokimia alga, misalnya lipid, terkait erat dengan struktur organ fotosintesis alga yang selalu beradaptasi terhadap intensitas cahaya yang ada (Harwood, 1988; Sukenik et al., 1989). Sebagai contoh, jenis $S$. platensis meningkatkan kandungan total lemaknya pada intensitas cahaya tinggi (Tedesco et al., 1989), sementara pada kondisi yang sama jenis Nannochloropsis sp. justru menurunkan kandungan total lemaknya (Sukenik et al., 1989).

Pada kultur mikroalga $C$. vulgaris dan Scenedesmus dimorphus, fenomena flashing

Biota Vol. 12 (1), Februari 2007 light effect yang didekati dengan kontrol distribusi kultur dalam tubular agar terpapar secara bertenggang pada cahaya yang ada di permukaan kolom, yaitu dengan mengalirkan kultur dalam kolom berpenyekat, menghasilkan peningkatan capaian kepadatan optik, kandungan klorofil sel, serta nilai rasio protein/karbohidrat secara konsisten (Chrismadha et al., 2000). Pada penelitian ini dilakukan uji coba lebih lanjut pada kultur mikroalga Ankistridesmus convulutus untuk pemahaman lebih luas dan mendalam fenomena tersebut.

\section{Metode Penelitian}

Kultur alga Ankistrodesmus convulutus ditumbuhkan pada kolom fotoreaktor tegak berpenyekat, dengan perlakuan variasi jarak penyekat, yaitu 1, 2, dan 3 inci, serta kontrol kolom fotoreaktor tanpa penyekat, dan laju tumbuh serta komposisi biokimia, meliputi konsentrasi biomasa, klorofil, protein, dan karbohidrat diamati. Fotobioreaktor terdiri dari kolom gelas berdiameter $10 \mathrm{~cm}$ dan tinggi 50 $\mathrm{cm}$, dengan volume kultur efektif $2500 \mathrm{ml}$ (Gambar 1), dilengkapi penyekat yang bersama-sama dengan kolom sentral dan aerasi berfungsi mengatur sirkulasi kultur mengalir bolak-balik ke permukaan dan bagian tengah kolom secara teratur untuk menciptakan efek radiasi cahaya intermitan pada sel-sel alga.

Dinding penyekat terbuat dari plat melamin tebal $1 \mathrm{~mm}$ yang ukurannya disesuaikan dengan diameter kolom gelas, terdiri dari penyekat dalam yang menempel pada kolom sentral dan berjarak $1 \mathrm{~cm}$ dari dinding kolom, serta penyekat luar yang menempel pada dinding kolom gelas dan berjarak $1 \mathrm{~cm}$ dari kolom sentral. Kedua penyekat tersebut dipasang berselang-seling sepanjang kolom gelas hingga permukaan kultur pada rangka 2 batang stainless steel, dimana jarak penyekat divariasikan sebagai perlakukan percobaan, yaitu: 1, 2, dan 3 inci. Kolom sentral terbuat dari pleksiglas berdiameter $22 \mathrm{~mm}$, berfungsi untuk mengakomodasi pergerakan sirkulasi kultur, yang didorong dengan tenaga aerasi (air lifting). 
Medium yang digunakan adalah medium PHM (Borowitzka, 1988) dengan $\mathrm{pH}$ awal 7, sedangkan sumber cahaya didapat dari 4 buah lampu TL 40 watt yang dipasang pada kedua sisi kolom fotoreaktor dengan intensitas cahaya terpasang pada permukaan kolom 5.500 luks. Inokulum didapat dari kultur dalam gelas kaca $500 \mathrm{ml}$ yang diaerasi berumur 2 minggu $(\mathrm{OD}=$ 1,8) dan diinokulasikan dengan sebesar $140 \mathrm{ml}$ untuk membentuk kepadatan awal sekitar OD $=0,1$. Setelah inokulasi, kultur dibiarkan tumbuh secara batch selama 14 hari, dan perkembangan kepadatan kultur diamati setiap hari menggunakan parameter kepadatan optik kultur, yang diukur menggunakan spektrofotometer pada panjang gelombang 450 $\mathrm{nm}$, dimana pada kondisi kultur terlalu pekat (OD>2,0) sampel kultur diencerkan dengan media kultur sesuai dengan tingkat kepadatannya untuk mendapatkan nilai bacaan kurang dari 2,0, dan dinai OD dihitung berdasar ekstrapolasi tingkat pengencerannya. Pengambilan sampel untuk parameterparameter biomasa, klorofil, karbohidrat, dan protein, dilakukan pada hari ke-7 (fase tumbuh eksponensial) dan ke-14 (awal fase stasioner). Percobaan dilakukan menggunakan empat ulangan.
Penghitungan kepadatan sel dilakukan pada haemasitometer di bawah mikroskop. Biomasa alga diekspresikan dalam berat organiknya, yang ditentukan dengan menyaring $3 \mathrm{ml}$ sampel melalui kertas saring Whatman GF/A yang sebelumnya telah dipanaskan pada $600^{\circ} \mathrm{C}$ selama satu jam. Setelah itu kertas saring dikeringkan dengan oven pada suhu $100^{\circ} \mathrm{C}$ semalam dan ditimbang. Untuk menentukan berat organik, kertas saring kemudian diabukan pada $600^{\circ} \mathrm{C}$ selama satu jam, dan setelah disimpan di dalam desikator yang berisi silika gel semalam, kertas saring tersebut ditimbang kembali. Bobot organik alga dihitung dengan mengurangi bobot kertas saring setelah dikeringkan dengan berat setelah diabukan.

Antara 2 - $5 \mathrm{ml}$ sampel juga disaring dengan menggunakan kertas saring Whatman GF/A untuk analisa kadar klorofil, karbohidrat total, dan protein total. Kandungan klorofil ditentukan dengan metode ekstraksi menggunakan aseton 90\% (Jeffrey \& Humprey, 1975). Kandungan karbohidrat total dianalisis dengan fenol-asam sulfat (Kochert, 1978), sementara total protein ditentukan dengan folin-fenol (Lowry et al., 1951).

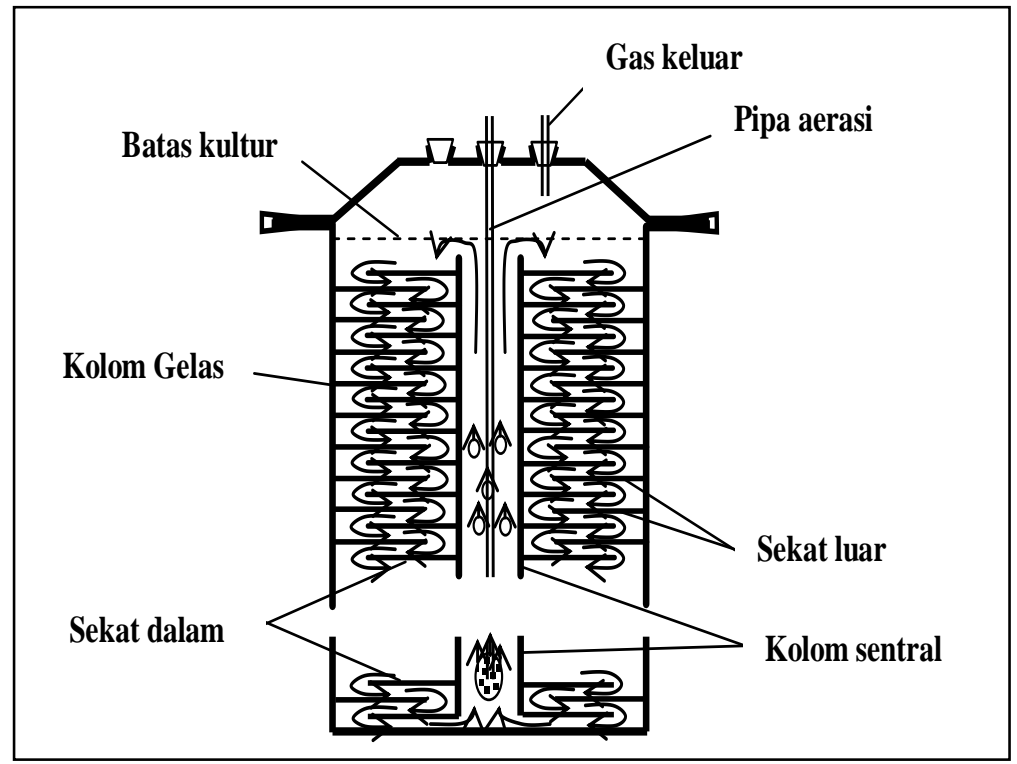

Gambar 1. Diagram fotobioreaktor tubular berpenyekat. 


\section{Hasil dan Pembahasan}

Hasil percobaan memperlihatkan bahwa cahaya intermitan yang dikontrol melalui jarak penyekat di dalam kolom fotoreaktor tidak memberikan pengaruh yang signifikan terhadap laju perkembangan kepadatan sel A. convulutus (Gambar 2), dengan nilai laju tumbuh berkisar antara 0,292 sampai dengan 0,315 pembelahan sel per hari. Hasil percobaan ini konsisten dengan hasil percobaan sebelumnya yang memperlihatkan pengaruh tidak nyata konstruksi penyekat pada fotobioreaktor berpenyekat terhadap pertumbuhan jenis $S$. dimorphus dan $C$. vulgaris (Chrismadha et al., 2002).

Konsentrasi maksimum biomasa yang dicapai selama 14 hari kultur adalah 2,58 g/l pada kultur dengan jarak penyekat 2 inchi, sekitar $14 \%$ lebih tinggi dibanding capaian biomasa kultur pada kolom tanpa penyekat (Gambar 2). Akan tetapi secara keseluruhan tidak terlihat pola pengaruh penyekat yang jelas terhadap produktivitas kultur alga tersebut, pada jarak penyekat 1 inchi dan 3 inchi capaian biomassa kultur justru lebih rendah dari pada kultur kontrolnya. Percobaan sebelumnya juga memperlihatkan peningkatan capaian konsentrasi biomasa pada $S$. dimorphus dan $C$. vulgaris akibat pemasangan konstruksi penyekat berjarak 2 inchi, yaitu $20 \%$ pada C. vulgaris dan $40 \%$ pada S. dimorphus (Chrismadha et al., 2002).

Seperti juga pada kultur $S$. dimorphus dan C. vulgaris (Chrismadha et al., 2002), konstruksi penyekat menstimulasi sintesis klorofil di dalam sel A. convulutus (Gambar 3). Kenaikan konsentrasi klorofil hingga $46 \%$ dicapai oleh kultur dengan jarak penyekat 2 inchi, sementara kultur berjarak penyekat 1 inchi mengalami kenaikan $24 \%$, dan kultur berjarak penyekat 3 inchi mengalami kenaikan 26\%. Respon kenaikan kandungan klorofil ini tidak setinggi pada kulur $S$. dimorphus dan C. vulgaris (Chrismadha et al., 2002), diduga karena intensitas cahaya yang digunakan pada percobaan ini lebih tinggi dibanding dengan percobaan sebelumnya (2500 luks). Seperti telah banyak dilaporkan intensitas cahaya tinggi pada umumnya menurunkan kandungan klorofil pada sel-sel mikroalga (Chrismadha et al., 1997).

Adanya peningkatan kandungan klorofil merupakan fenomena yang sangat menarik dalam pengembangan fotobioreaktor berpenyekat. Hal ini dikaitkan dengan potensi mikroalga sebagai sumber potensial berbagai jenis pigmen dan asam lemak tak jenuh rantai panjang (poly unsaturated fatty acis; PUFA), yang proses sintesisnya terkait erat dengan pembentukan organ fotosintesis alga. Seperti telah dilaporkan sebelumnya, bahwa jenis-jenis PUFA, khususnya $\mathrm{C}_{20: 5}$ dan $\mathrm{C}_{20: 4}$, pada umumnya terikat pada galaktolipid (Sukenik et al., 1989; Sukenik \& Wahnon, 1991) yang laju sintesisnya terkait dengan pembentukan membran tilakoid yang sangat dipengaruhi oleh cahaya. Peningkatan kandungan klorofil pada kultur alga yang tumbuh dalam kolom fotobioreaktor berpenyekat kemungkinan juga diikuti dengan meningkatnya kandungan PUFA alga-alga tersebut.

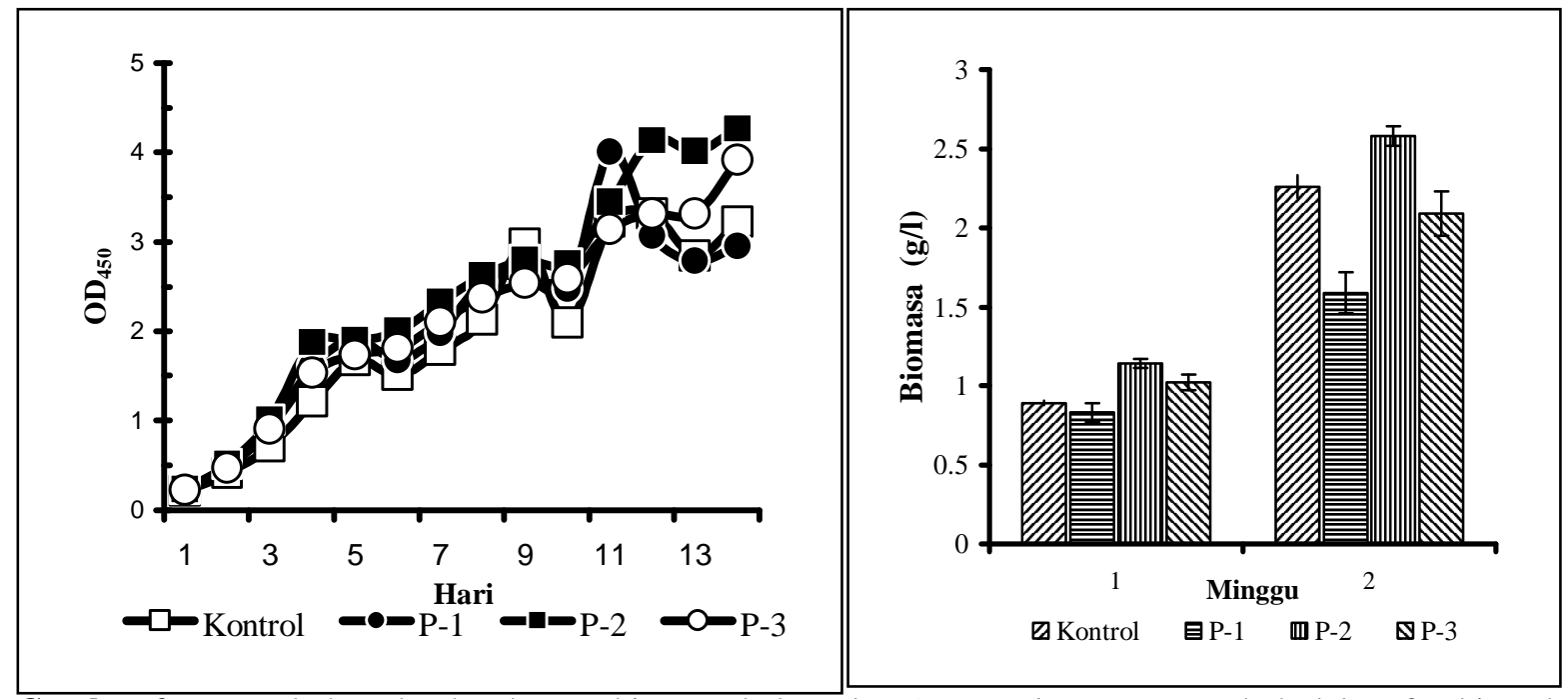

Gambar 2. Pertumbuhan dan kandungan biomasa kultur alga A. convulutus yang tumbuh dalam fotobioreaktor dengan variasi jarak penyekat: $\mathrm{P}-1=1$ inci, $\mathrm{P}-2=2$ inci, dan $\mathrm{P}-3=3$ inci 
Konstruksi penyekat secara konsisten juga meningkatkan sintesa protein pada kultur A. convulutus, yaitu hingga $86 \%$ pada jarak penyekat 2 inchi, $43 \%$ pada jarak penyekat 1 inchi, dan $50 \%$ pada jarak penyekat 3 inchi (Gambar 3), sementara konstruksi penyekat tersebut tidak memperlihatkan pengaruh yang nyata terhadap kandungan karbohidrat kultur $A$. convulutus, meskipun sedikit kenaikan tampak pada minggu kedua (Gambar 3). Kandungan klorofil dan protein yang tinggi memberikan indikasi adanya optimalisasi proses katalitik lanjut dari produk awal fotosintesis menjadi organ struktur fungsional sel. Bila diperhatikan bahwa faktor pembatas tumbuh kultur mikroalga ialah laju reaksi katalitik tersebut (Raven, 1988), terutama pada intensitas cahaya tinggi (Goldman, 1979), maka struktur penyekat menjadi alternatif menarik untuk meningkatkan laju tumbuh dan produktivitas mikroalga, khususnya berkaitan dengan pengembangan desain fotobioreaktornya. Dari hasil penelitian ini terlihat perlunya menentukan desain konstruksi penyekat optimum agar keunggulan fenomena tersebut dapat dimanfaatkan untuk meningkatkan produktivitas kultur alga. Hal ini perlu diperhatikan mengingat tingkat produktivitas yang lebih rendah pada jarak penyekat 1 inci dan 3 inci dibanding dengan kultur kontrolnya, yang memperlihatkan indikasi adanya peningkatan respirasi sel akibat pemasangan konstruksi penyekat tersebut.
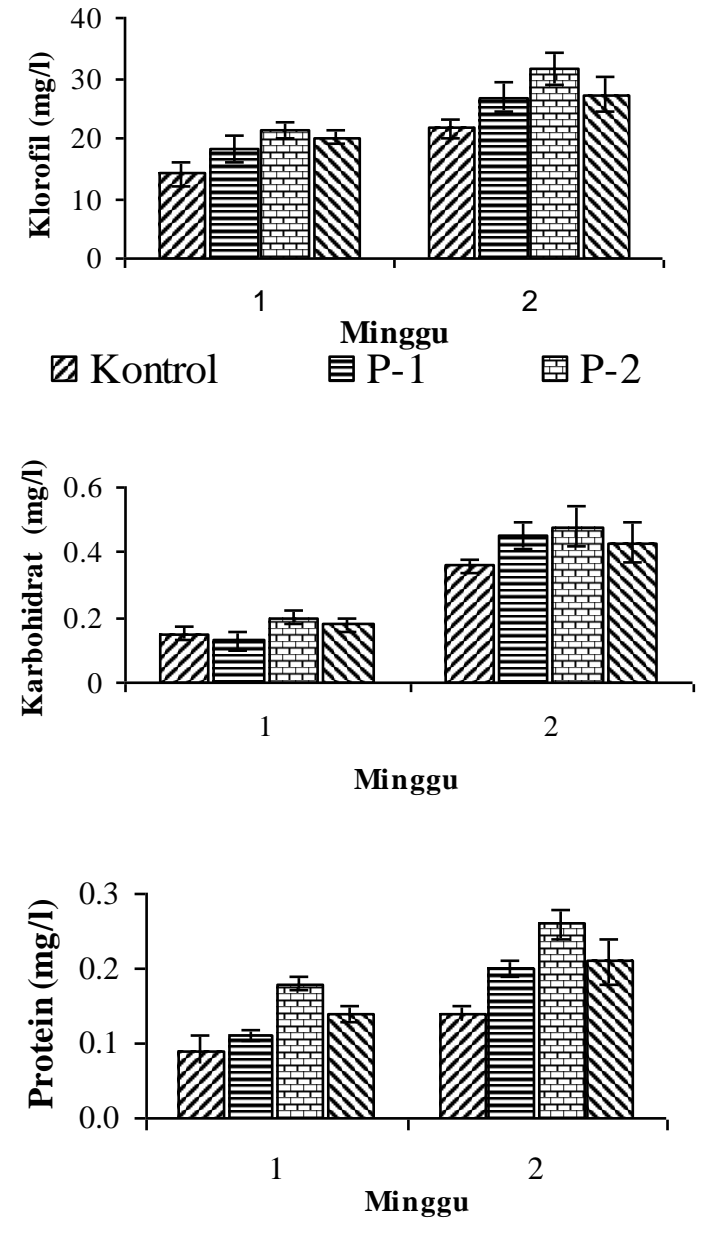
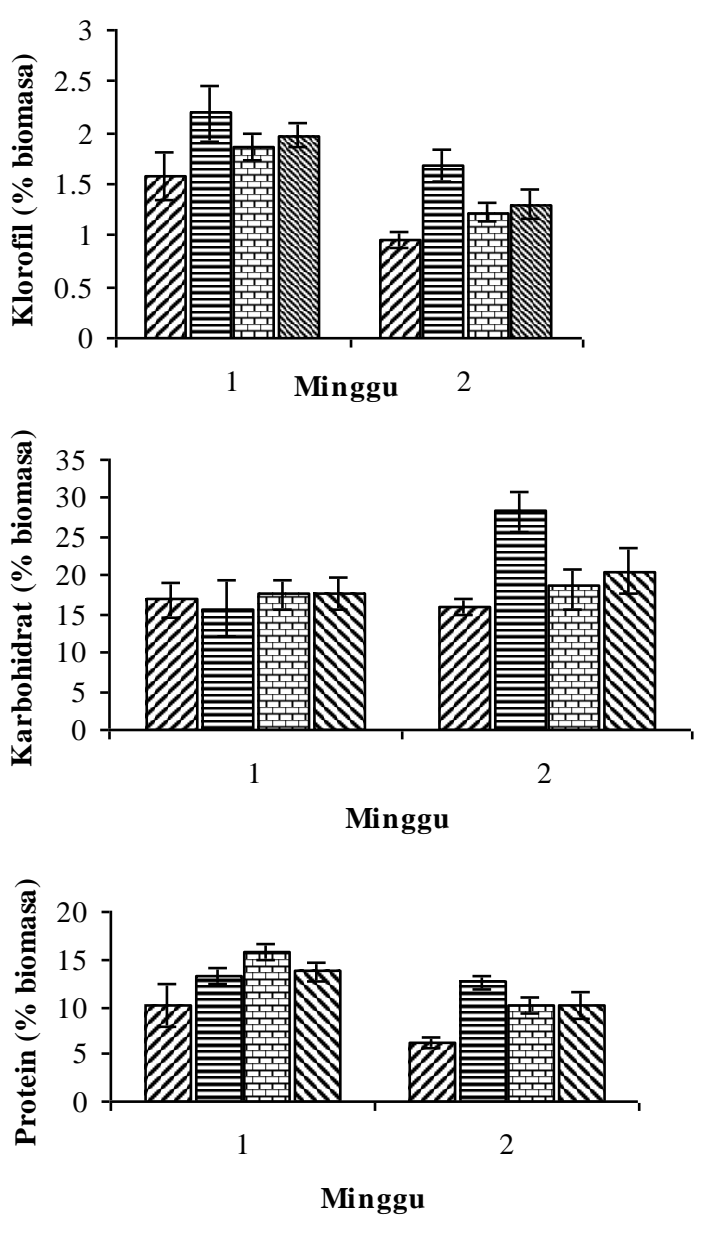

Gambar 3. Komposisi biokimia kultur alga A. convulutus yang tumbuh dalam fotobioreaktor dengan variasi jarak penyekat: $\mathrm{P}-1=1$ inci, $\mathrm{P}-2=2$ inci, dan $\mathrm{P}-3=3$ inci 
Raven (1984) menerangkan bahwa sintesis pigmen berlebihan merupakan pola adaptasi sel-sel mikroalga terhadap kondisi intensitas cahaya yang rendah, dan memerlukan alokasi budget energi sel, sehingga mengurangi tingkat efisiensi pertumbuhan sel. Namun fenomena demikian menjadi menarik bila diperhatikan permasalahan pengembangan kultur di tempat terbuka, khususnya di daerah tropis, dimana intensitas cahaya yang sangat tinggi menjadi salah satu faktor pembatas utama. Pemaparan secara bertenggang pada cahaya tinggi melalui struktur reaktor berpenyekat dapat menjadi salah satu alternatif pemecahan masalahnya. Penelitian-penelitian lebih lanjut untuk mengungkap lebih jauh mekanisme adaptasi cahaya dan kaitannya dengan pengembangan fotobioreaktor untuk produksi biomassa mikroalga masih perlu untuk terus dilakukan, khususnya dalam rangka meningkatkan daya adaptasi kultur mikroalga pada intensitas cahaya matahari yang sangat tinggi di tempat terbuka.

\section{Kesimpulan}

Hasil penelitian menunjukkan bahwa jarak penyekat dalam fotobioreaktor tegak tidak berpengaruh nyata terhadap perkembangan kepadatan optik kultur $A$ convulutus, namun berpengaruh secara signifikan terhadap capaian biomassanya. Jarak penyekat juga berpengaruh nyata terhadap kandungan klorofil dan rasio protein/karbohidrat sel-sel alga tersebut. Hal ini merupakan indikasi bahwa pemaparan terhadap cahaya bertenggang di bagian permukaan kolom reaktor mendorong terjadinya sinkronisasi antara reaksi gelap dan reaksi terang proses fotosintesis alga, serta mengoptimalkan proses katalitik lanjut dari produk awal fotosintesis menjadi organ struktur fungsional sel. Dengan demikian konstruksi penyekat dapat dimanfaatkan untuk meningkatkan produktivitas kultur mikroalga dalam fotobioreaktor tubular, khususnya dalam upaya pemanfaatan intensitas cahaya alami yang relatif tinggi.

\section{Daftar Pustaka}

Borowitzka, M.A. 1988. Algal Growth Media Sources of Algal Cultures. In: Borowitzka, M.A. and Borowitzka, L.J. (Eds.). Microalgal Biotechnology, pp. 456 - 465. Cambridge University Press, Cambridge.

Borowitzka, M.A. and Borowitzka, L.J. 1989. Industrial Production: Methods and Economics. In: Rees, T.A.V. and Shah, N. (Eds.). Algal and Cyanobacterial Biotechnology, pp. 294-315. Longman Scientific and Technical. London.

Chrismadha, T. and Borowitzka, M.A. 1994. Effect of Cell Density and Irradiance on Growth, Proximate Composition and Eicosapentanoic Acid Production of Phaeodactylum tricornutum Grown in a Tubular Photobioreactor. Journal of Applied Phycology 6: 67-74.

Chrismadha, T., Rosidah dan Mardiyati, Y. 2002. Pengaruh Penyekat pada Fotobioreaktor Tubular terhadap Pertumbuhan dan Komposisi Biokimia Mikroalga. Poster dipresentasikan pada Kongres III Konsorsium Bioteknologi Indonesia (KBI) dan Seminar Bioteknologi 2002. Bandung, 10-11 Oktober 2002.

Chrismadha, T., Nasution, S.H., Mardiati, Y. dan Kurniasih, A. 1997. Respon tumbuh alga Ankistrodesmus convulutus dan Chlorella sp terhadap Intensitas Cahaya. Makalah dipresentasikan pada: Ekspose Hasil Penelitian Puslitbang Limnologi 1996/1997. Cibinong, 18 - 19 Maret 1997.

Chrismadha, T, Sutapa, I.D.A., Hidayat, Rosidah dan Mardiati, Y. 2000. Pengaruh Cahaya Intermitan terhadap Fotosintesis Kultur Alga Chlorella vulgaris. Makalah dipresentasikan pada Seminar Nasional Biologi VIII. Bandung, 17 Juli 2000

Fernandez-Reiriz, M.J., Camacho, A.P., Ferreiro, M.J. and Labarta, U. 1989. Biomass Production and Variation in the Biochemical Profile of Seven Species of Marine Microalgae. Aquaculture 83: 17-37.

Goldman, J.C. 1979. Outdoor Algal Mass Culture. II: Photosynthetic Yield Limitations. Water Research 13: 119-136.

Grobbelar, J.U. 1989. Do light/dark cycles of medium frequency enhance phytoplankton productivity? Journal of Applied Phycology 1: 333-340.

Harwood, J.L. 1988. Fatty Acids Metabolism. Annual Review of Plant Physiology and Plant Molecular Biology 39: 101 - 138 


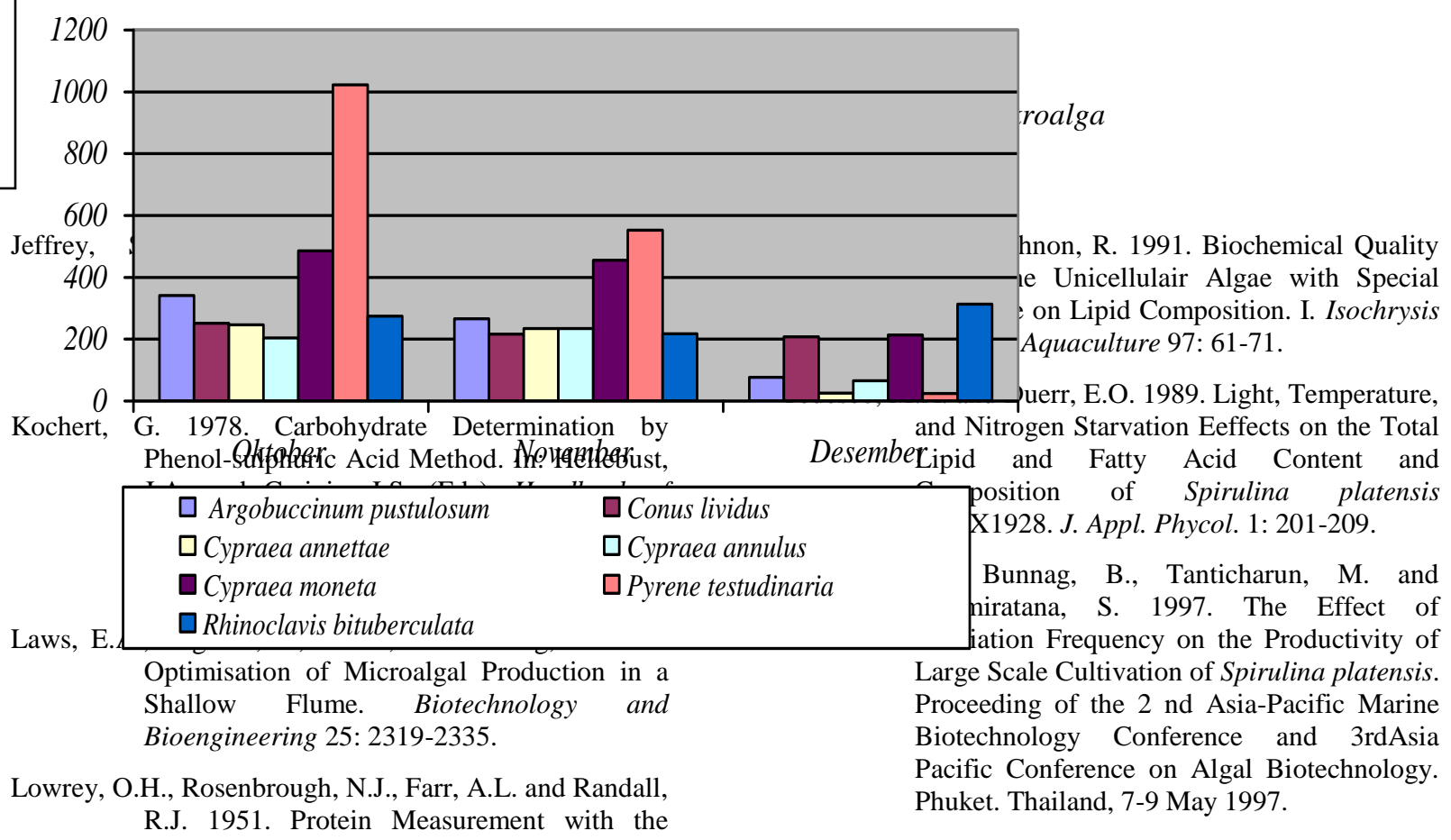
Folin Phenol Reagent. The Journal of Biological Chemistry 1983: 265-275.

Rabe, A.E. and Benoit, J. 1962. Mean Light Intensity - A Useful Concept in Correlating Growth Rates of Dense Cultures of Microalgae. Biotechnology and Bioengineering 4: 377 390.

Raven, J.A. 1984. A Cost Benefit Analysis of Photon Absorption by Photocynthetic Unicells. New Phytologist 98: 593-625.

Raven, J.A. 1988. Limits to Growth. In: Borowitzka, M.A. and Borowitzka, L.J. (Eds.). Microalgal Biotechnology, pp. 331 - 387. Cambridge University Press, Cambridge.

Sukenik, A. 1991. Ecophysiological Consideration in Optimization of Eicosapentanoic Acid Production by Nannochloropsis sp. (Eustigmatophyceae). Bioresource Technology 35: 263-269.

Sukenik, A., Carmely, Y. and Berner, A. 1989. Regulation of Fatty Acid Composition by Irradiance Level in the Eustigmatophyte Nannochloropsis sp. Journal of Phycology 25: 686-692. 